\section{Bystander, czyli kto? \\ Potoczne wyobrażenia Polaków \\ na temat stosunku do Żydów w czasie okupacji hitlerowskiej}

Michał Bilewicz, Maria Babińska

TEKSTY DRUGIE 2018, NR 3, S. 97-116

DOI: $10.18318 /$ td.2018.3.6

\section{Polacy - zbiorowy bystander?}

Pojęcie świadka - do niedawna często stosowane w odniesieniu do pozycji zajmowanej przez etnicznych Polaków wobec zagłady Żydów - coraz częściej wzbudza sprzeciw wielu badaczy Holokaustu. Twierdzenie, że polska pamięć Holokaustu jest pamięcią biernych świadków, stanowiło do niedawna milczące założenie we wszystkich ważniejszych pracach dotyczących Zagłady. Jan Błoński w latach 8o. pisał o „zaniechaniu czy przeciwdziałaniu niedostatecznym"1 jako źródle współwiny Polaków, którzy jako naród nie brali udziału w zbrodni ludobójstwa. W pracy Pamięć nieprzyswojona amerykański badacz Michael Steinlauf, podejmując się próby analizy polskiej pamięci Holokaustu, przyjął za podstawę koncepcję „winy wobec śmierci", którą odczuwają bierni świadkowie². Świadkowie zbrodni żyją z poczuciem winy wynikającym

1 J. Błoński Biedni Polacy patrza na getto, "Tygodnik Powszechny” 1987 nr 2.

2 M. Steinlauf Pamięć nieprzyswojona: polska pamięć zagłady, Wydawnictwo Cyklady, Warszawa 2001.
Artykuł powstał w ramach projektu NCN Beethoven 2014/15/G/HS6/04589 dotyczącego społecznej percepcji historii.

Michał Bilewicz psycholog społeczny i kierownik Centrum Badań nad Uprzedzeniami UW. Jego badania koncentrują się na tematyce kontaktu międzygrupowego, pamięci zbiorowej i społecznej psychologii języka. Kontakt: bilewicz@ psych.uw.edu.pl

\section{Maria Babińska}

- psycholożka społeczna, asystentka na Wydziale Psychologii UW. Zajmuje się rolą motywacji psychologicznych w postrzeganiu historii oraz psychologicznymi aspektami seksizmu. Kontakt: maria. babinska@psych. uw.edu.pl 
z braku odpowiedniej reakcji - co w efekcie prowadzi do potrzeby wypierania z pamięci traumatyzującego doświadczenia.

We wszystkich tych analizach pozycja Polaków jako zbiorowych świadków Holokaustu jest przyjmowana jako sprawa oczywista - to bierność ma być największym moralnym wyzwaniem, z którym zmierzyli się Polacy w czasie Holokaustu i które doprowadziło do poczucia winy czy negacji. Współcześni badacze Holokaustu podkreślają jednak, że pojęcie świadka (bystander) jest niezwykle trudne do obrony - świadkowie byli bowiem nieraz uwikłani we współsprawstwo i równocześnie czerpali z tego korzyści bądź próbowali uchronić się przed losem ofiar.

Opór badaczy tego zjawiska może wynikać z problemu z samym pojęciem bystander i jego polskim tłumaczeniem. Jak zauważa Jan Woleński, pojęcie to oznacza nie tyle świadka, co biernego postronnego obserwatora, nieuczestniczącego w zdarzeniu ${ }^{3}$. W tym sensie słowo to zdaje się zacierać faktyczną rolę Polaków w Holokauście. W pracy Sprawcy, ofiary i inni ${ }^{4}$ Jan Tomasz Gross zauważa, że słowo bystander implikuje nic-nie-robienie, nie-zaangażowanie i nie-zainteresowanie, których nijak nie można odnieść do historii świadków Holokaustu. Bożena Karwowska sugeruje wręcz, by w anglojęzycznej literaturze dotyczącej Holokaustu porzucić pojęcie bystandera i zastąpić czymś, co będzie bliższe wschodnioeuropejskiemu rozumieniu świadka - osoby uwikłanej w samo ludobójstwo 5 .

We współczesnej historiografii Holokaustu polskie pojęcie „świadka” jest również coraz częściej odrzucane jako nieadekwatne do pozycji zajmowanej przez Polaków wobec zagłady Żydów. Elżbieta Janicka postuluje „odrzucenie koncepcji polskiej większości jako bystanders czy onlookers - gapia, postronnego obserwatora czy świadka (na rzecz obserwatora uczestniczącego) - oraz koncepcji polskiego doświadczenia Zagłady jako zbiorowej traumy"6. Jej zdaniem już samo pojęcie świadka jest mylące gdyż zarówno zachowania, jak i komunikaty werbalne i niewerbalne ze

3 J. Woleński Executioners, Victims and Bystanders, w: Holocaust. Voices of Scholars, red. J. Ambrosiewicz-Jakobs, Jagiellonian University, Centre for Holocaust Studies, Auschwitz-Birkenau State Museum, Kraków 2009. s. 267-278.

4 J.T. Gross Sprawcy, ofiary i inni. „Zagłada Żydów” 2014 nr 10, s. 885-888.

5 B. Karwowska Bystanderczy (pasywny) świadek? Kilka uwag nad konsekwencjami wyboru terminologii w badaniach nad Zagładq̨ lub Holocaustem, "Roczniki Humanistyczne” 2017 nr 64/1, s. 91-98.

6 E. Janicka Pamięć przyswojona. Koncepcja polskiego doświadczenia zagłady Żydów jako traumy zbiorowej w świetle rewizji kategorii świadka ,"Studia Litteraria et Historica” 2015 nr 3/4, s. 148-226. 
strony Polaków budowały strukturę przemocy symbolicznej w epoce Zagłady. Warto zwrócić uwagę, że w podejściu tym przyjmuje się, że bystander musiałby być nie tylko nie-działającym świadkiem, lecz również świadkiem nie-mówiącym i nie-komunikującym. Pozycję taką w warunkach ludobójstwa trudno sobie wyobrazić. W psychologii społecznej pojęcie bystandera jest jednak rozumiane znacznie szerzej i w niniejszej pracy zastanowimy się nad jego możliwym zastosowaniem w analizach Holokaustu i społecznych reprezentacji Zagłady w Polsce.

\section{Sprawcy - ofiary - świadkowie: esencjalizm triady Hilberga}

Pojęcie narodu jako zbiorowego bystandera jest ewidentnie elementem esencjalistycznego myślenia o przeszłości - w którym całym grupom narodowym bądź etnicznym przypisuje się jednolitą rolę w jakimś wydarzeniu historycznym. We współczesnych interpretacjach ludobójstw często przywołuje się schematyczne rozumienie trzech ról, jakie mogą przyjmować ludzie wobec zbrodni: sprawcy, ofiary i świadka (bystander) ${ }^{7}$. Na takie właśnie trzy części podzielił swoją monumentalną pracę na temat historii Holokaustu Raul Hilberg.

W potocznym rozumieniu ludobójstw często za sprawców, ofiary i świadków uznaje się całe narody. Można to jednak uznać za uogólnienie, które raczej utrudnia niż ułatwia zrozumienie mechanizmów i złożoności ludobójstwa. Przywiązanie do kategorii narodowych możliwe jest dzięki zjawisku esencjalizacji: dostrzegania pewnej esencji łączącej wszystkich członków danego narodu, a przez to determinującej zachowania każdego z nich. W myśleniu o historii esencjalizm sprowadza się do postrzegania całych narodów jako odpowiedzialnych za zbrodnie - a innych za będących wyłącznie ofiarami bądź świadkami. W esencjalistycznym myśleniu grupy narodowe są trwałe w czasie, a odpowiedzialność przekazywana jest z pokolenia na pokolenie podobnie jak status ofiary, świadka czy sprawcy ${ }^{10}$.

7 Por. E. Staub The Psychology of Bystanders, Perpetrators, and Heroic Helpers, "International Journal of Intercultural Relations" 1993 No. 17.3, S. 315-341.

8 R. Hilberg The Destruction of the European /ews, Yale University Press, New Haven, CT 1961.

9 M. Verkuyten Discourses About Ethnic Group (De-) Essentialism: Oppressive and Progressive Aspects, "British Journal of Social Psychology” 2003 No. 42.3, s. 371-391.

10 F. Sani i in. Perceived Collective Continuity: Seeing Groups as Entities that Move Through Time, „European Journal of Social Psychology" 2007 No. 37/6, s. 1118-1134. 
„Trójkąt ludobójstwa” to jednak uproszczenie bardzo niebezpieczne. Bardzo trudno zgodzić się co do statusu konkretnych narodów. W klasycznym rozumieniu historii Holokaustu przedstawia się Niemców jako sprawców, Żydów jako ofiary, a pozostałe narody okupowanej Europy jako świadków zbrodni. Oczywiście taka typologia nie uwzględnia innych ofiar zbrodni nazistowskich, co powoduje niekończącą się rywalizację cierpień między narodami, których status ofiar nie został dostatecznie uznany" ${ }^{11}$. Również esencjalizacja sprawców jest nadużyciem - nie pozwala bowiem na uznanie dość oczywistego faktu, że zbrodnia Holokaustu nie byłaby tak skuteczna bez współudziału innych narodów, a nawet samych ofiar ${ }^{12}$.

Myślenie esencjalistyczne, poza upraszczaniem rzeczywistości, powoduje też, że można jasno określić współczesnych winnych historycznych zbrodni oraz umożliwia mobilizację potencjału niechęci wobec potomków sprawców. Badania Michaela Wohla i Nyli Branscombe ${ }^{13}$ wykazały, że samo podkreślenie niemieckiego sprawstwa zbrodni w przeciwieństwie do ogólnoludzkiego wymiaru Holokaustu zwiększa wśród kanadyjskich Żydów nienawiść wobec współczesnych Niemców i chęć unikania ich w otoczeniu. Nasze niedawne badania potwierdziły, że zarówno Polacy, jak i Izraelczycy skłonni do esencjalistycznego rozumienia Holokaustu deklarowali znacznie bardziej negatywny stosunek do współczesnych Niemców ${ }^{14}$.

Czy jednak kategoria bystandera musi być używana w sposób esencjalistyczny? Można bowiem przyjąć, że to nie cały naród przyjmuje jedną rolę wobec ludobójstwa - lecz raczej to architekci ludobójstwa determinują możliwe role, które przyjmują różne grupy etniczne, religijne czy narodowe. Zastanawiając się nad rolą bystandera w ludobójstwie, warto przypomnieć genezę tego pojęcia w naukach społecznych i przeprowadzić psychologiczną analizę pozycji bystandera w czasie Holokaustu.

11 I. Young, D. Sullivan Competitive Victimhood:A Review of the Theoretical and Empirical Literature, "Current Opinion in Psychology" 2016 No. 11, s. 30-34.

12 Z. Bauman Nowoczesność i Zagłada, Fundacja Masada, Kraków: 1992.

13 J.M. Wohl, N.R. Branscombe, Y. Klar Collective Guilt: Emotional Reactions When One's Group Has Done Wrong or Been Wronged, "European review of social psychology” 2006 No. 17/1, s. 1-37.

14 R. Imhoff, M. Bilewicz, K. Hanke $\mathrm{i}$ in. Explaining the Inexplicable: Differences in Attributions for the Holocaust in Germany, Israel, and Poland, "Political Psychology" 2017 No. 38.6, S. 907-924. 


\section{Efekt bystandera, czyli jak psychologowie społeczni stworzyli pewne pojęcie}

Pojęcie bystander w anglojęzycznej literaturze rozpowszechniało się od drugiej połowy lat 6o. Wizualizacja częstości pojawiania się słów w książkach anglojęzycznych (dzięki zastosowaniu programu Google NGram) wskazuje, że między rokiem 1965 a 1975 następuje skokowy wzrost częstości używania tego pojęcia. Wcześniej było ono używane stosunkowo rzadko, a po 1975 roku jego częstość już nie wzrastała.

Wydarzeniem, które z pewnością miało wpływ na rozpowszechnienie się pojęcia bystander, była zbrodnia, do jakiej doszło w 1964 roku w Nowym Jorku. Mieszkanka dzielnicy Queens, Katherine Genovese, została napadnięta i zamordowana przez seryjnego zabójcę. Wydarzenie to zostało nagłośnione przez prasę, która podkreślała bierność świadków tego wydarzenia - rzekomo 38 osób miało widzieć scenę mordu i nie zareagować na wołanie ofiary o pomoc ${ }^{15}$.

Wydarzenie to zainspirowało wielu psychologów społecznych do badań nad zjawiskiem, które wkrótce nazwano bystander-effect, tłumaczonym na polski jako „efekt świadka”, ,efekt widza” czy „efekt rozproszenia odpowiedzialności". Najważniejsze prace dotyczące tego zjawiska, takie jak The Unresponsive Bystander: Why doesn't He Help? czy Bystander Intervention in Emergencies: Diffusion of Responsibility Johna Darleya i Bibba Latané próbowały wyjaśniać bierność świadków zbrodni apatią wywoływaną przez świadomość obecności innych świadków w otoczeniu ${ }^{16}$. Badania te sugerowały, że najbardziej oczywistym zachowaniem w tego typu sytuacjach jest raczej bierność niż udzielenie pomocy. Wynika to z wielostopniowego procesu decyzyjnego, który poprzedza udzielenie pomocy - obejmuje on 1. zauważenie zdarzenia, 2. interpretację zdarzenia jako wymagającego interwencji, 3. poczucie odpowiedzialności za los ofiary, 4. wybór sposobu pomocy i 5. udzielenie pomocy. Na każdym z tych etapów istnieje wiele czynników ograniczających skłonność do pomagania.

Spośród licznych prac psychologów społecznych na przełomie lat 60. i 70. warto wspomnieć o badaniach Elaine Walster i Jane Piliavin, opisanych $\mathrm{w}$ artykule Equity and the Innocent Bystander i późniejszych pracach. Autorki te sugerują, że zachowania bystandera nie można sprowadzić do problemu

15 R. Manning, M. Levine, A. Collins The Kitty Genovese Murder and the Social Psychology of Helping: The Parable of the 38 Witnesses, "American Psychologist” 2007 No. 62/6, s. 555-562.

16 J. Darley, B. Latané Bystander Intervention in Emergencies: Diffusion of Responsibility, "Journal of Personality and Social Psychology" 1968 No. 8/4.1, s. 377-383. 
rozproszenia odpowiedzialności. Decyzja o reagowaniu bądź niereagowaniu to ciągła kalkulacja korzyści i kosztów. Bierność pociąga za sobą oczywiste koszty psychologiczne (stres w konfrontacji z cierpieniem ofiary, koszty wizerunkowe), podobnie zresztą jak zareagowanie (ryzyko w konfrontacji ze sprawcą, kontakt z krwią etc.) ${ }^{\mathbf{1 7}}$. W modelu tym zachowanie bystandera jest już czymś więcej niż byciem niezaangażowanym "gapiem” (jak to ujmują Janicka i Gross). Jest to strategiczny wybór, w którym niektóre działania mają wyższą wartość moralną, a niektóre niższą.

Nagromadzenie badań psychologicznych na temat pomagania i altruizmu w dekadzie 1965-1975 przełożyło się na zwiększone zainteresowanie tematem wśród opinii publicznej. Pojęcie bystander trafiło również do innych nauk, zaczęło coraz częściej pojawiać się w pracach historyków, antropologów i socjologów. Jego znaczenie zostało jednak trwale ukształtowane przez wczesne badania Darleya i Latané, przez co prototypem bystandera stał się bierny świadek przyglądający się cierpieniu ofiary z nadzieją, że ktoś inny ruszy jej z pomocą. Takiego rozumienia pojęcia bystandera rzeczywiście nie daje się zastosować do opisu relacji polsko-żydowskich w czasie Holokaustu. Postulujemy jednak, aby zastanowić się nad bardziej współczesnymi odkryciami psychologii społecznej, które pozwalają nieco zniuansować pojęcie bystandera - tak by można było je trafnie zastosować również do opisu najbardziej krańcowych sytuacji, do których dochodziło podczas ludobójstw.

\section{Bystander na mapie sprawczości i wspólnotowości}

Dwa podstawowe wymiary, na jakich ludzie opisują cechy swoje oraz cechy innych ludzi, to wymiar sprawczości i wspólnotowości ${ }^{18}$. Wymiar sprawczości to oceny, czy dana osoba jest sprawcza (czy jest podmiotowa, kontroluje działania swoje i innych, czy jest inteligentna, zaradna). Wymiar wspólnotowości odnosi się z kolei do moralności i intencji (czy opisywany człowiek jest uczciwy, moralny, troskliwy, przyjazny). Te dwa podstawowe wymiary poznania społecznego można odnieść także do sposobu, w jaki można postrzegać sytuację bystandera.

17 I.M. Piliavin, J.A. Piliavin, J. Rodin Costs, Diffusion, and the Stigmatized Wictim, "Journal of Personality and Social Psychology" 1975 No. 32/3, s. 429-438. 


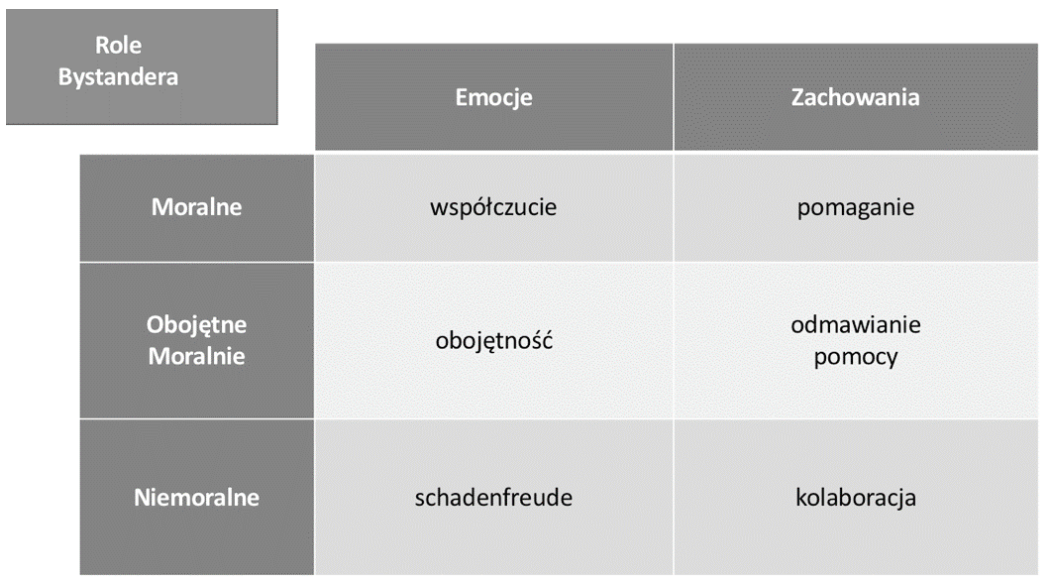

Ryc. 1. Struktura zachowań i emocji bystanderów w kontekście stosunku etnicznych Polaków do Żydów w czasie okupacji.

Na wymiarze sprawczości zachowania bystanderów można opisać jako czynne (działanie bystandera wobec ofiary) i bierne (emocje bystandera wobec ofiary). Choć w większości opracowań historycznych dotyczących Holokaustu koncentrowano się na zachowaniach czynnych w czasie okupacji (udzielanie bądź odmowa pomocy, kolaboracja, rabunki itp.), to warto zwrócić uwagę również na zachowania bierne. Jak zauważa Elżbieta Janicka ${ }^{19}$, na podstawie literatury wspomnieniowej i historycznej dotyczącej Holokaustu „na wszystkich trzech etapach Zagłady - przez całą okupację - Żydzi odbierali wysyłane przez Polaków komunikaty: werbalne i pozawerbalne. Komunikaty te tworzyły kontinuum z większościowymi postawami i zachowaniami wobec Żydów przed wojną". Komunikaty niewerbalne były bezpośrednim wyrazem emocji odczuwanych wobec cierpienia Żydów.

\section{Emocje wobec Zagłady: bierne oblicze bystandera}

Zastanawiając się nad emocjonalnymi reakcjami Polaków na zagładę Żydów, warto podkreślić dwa uczucia: empatię, schadenfreude oraz emocjonalną bierność - brak jakiejkolwiek emocjonalnej reakcji. W Kronice lat wojny i okupacji Ludwik Landau opisuje reakcje polskiego społeczeństwa na walki w getcie warszawskim:

19 E. Janicka Pamięć przyswojona. Koncepcja polskiego doświadczenia zagłady Żydów jako traumy zbiorowej w świetle rewizji kategorii świadka, "Studia Litteraria et Historica” 2015 No. 3/4, s. 148-226. 
Stosunek uczuciowy do tej walki jest różny: gdy u jednych nacechowany jest sympatią do stawiających bohaterski opór ofiar hitlerowskich, u innych łączący się z wyjątkowo złowrogie wrażenie wywierającym w takiej chwili antysemityzmem, a bodajże u większości stanowiący obserwację neutralnego widza. ${ }^{20}$

Emocja schadenfreude definiowana jest jako bierna, oportunistyczna i pośrednio odczuwana przyjemność z cierpienia innego człowieka czy innej grupy (np. narodowej) ${ }^{21}$. Psychologowie odwołują się tu do Nietzschego, który określał schadenfreude jako przyjemność słabych odczuwaną z powodu nieszczęścia tych, których uważają za silniejszych od siebie ${ }^{22}$. Schadenfreude jest więc powiązane z doświadczeniem niemocy - i daje iluzję sprawstwa tym, którzy są pozbawieni wpływu na bieg wydarzeń. Przyjemność ta wynika głównie z wcześniejszej zawiści odczuwanej wobec danej grupy ${ }^{23}$. Psychologia społeczna od dawna wskazuje na fundamentalną rolę zawiści w stereotypie Żydów w międzywojennych Niemczech i w Polsce, na zawiści zbudowane były stereotypy sugerujące majętność Żydów, ich związki z pieniędzmi, insynuujące kontrolę gospodarki i polityki przez żydowski spisek ${ }^{24}$. Mina Cikara i Susan Fiske, badając fizjologiczne przejawy emocji schadenfreude, zauważyły, że nieszczęście doznawane przez przedstawicieli grup o wysokim statusie, wobec których badani zwykle odczuwają zawiść, wywołuje napięcie mięśni typowe dla odczucia przyjemności (większa aktywność mięśni zygomatycznych). Emocja schadenfreude blokuje empatię, czyli zdolność do współodczuwania i współcierpienia. Z drugiej strony zawiść prowadzi do

20 L. Landau Kronika lat wojny i okupacji, t. 2, PWN, Warszawa 1962.

21 C. Leach, R. Wayne, R. Spears, A. Manstead Situating Schadenfreude in Social Relations, w: Schadenfreude: Understanding Pleasure at the Misfortune of Others, ed. by W. van Dijk, J.W. Ouwerkerk, Cambridge University Press, Cambridge, MA 2014. s. 200-217.

22 F. Nietzsche Zgenealogii moralności, przeł. G. Sowiński, Znak, Kraków 1997.

23 M. Cikara, S. Fiske Stereotypes and Schadenfreude: Affective and Physiological Markers of Pleasure at Outgroup Misfortunes, "Social Psychological and Personality Science” 2012 No. 3/1, s. 63-71; W.W. Van Dijk, J.W. Ouwerkerk, S. Goslinga,M. Nieweg, M. Gallucci When People Fall from Grace: Reconsidering the Role of Envy in Schadenfreude, "Emotion” 2006 No. 6/1, s. 156-160.

P. Glick Sacrificial Lambs Dressed in Wolves' Clothing, w: Understanding Genocide: The Social Psychology of the Holocaust, ed. by L. Newman, R. Erber, Oxford University Press, Oxford 2002 s. 113-X; M. Winiewski, W. Soral, M. Bilewicz Conspiracy Theories on the Map of Stereotype Content: Survey and Historical Evidence, w: The Psychology of Conspiracy, ed. by M. Bilewicz, A. Cichocka, W. Soral, Routledge, London 2015, s. 23-43. 
schadenfreude tylko wtedy, gdy nieszczęście spotyka ludzi do nas w pewien sposób podobnych - ich los musi być w jakimś stopniu zbliżony do naszego ${ }^{25}$.

Powyższy paradoks emocji schadenfreude zdaje się odpowiadać relacjom polsko-żydowskim czasu okupacji. Silne przed wojną stereotypy zawistne przy jednoczesnej bliskości kulturowej Polaków i Żydów utworzyły psychologiczne podglebie, na którym tragedia Żydów mogła często spotykać się z satysfakcją i wręcz przyjemnością etnicznych Polaków. Odwołując się do koncepcji psychoanalitycznych, Andrzej Leder nazywa ten rodzaj przyjemności „transpasywną"26 - źródłem przyjemności ma być to, że zewnętrzne siły dopełniają procesu modernizacji poprzez usunięcie z przestrzeni społecznej Żydów, postrzeganych jako ograniczających szanse Polaków na awans.

Wiele obrazów wskazujących na emocję schadenfreude można znaleźć na kartach literatury pięknej i wspomnieniowej. W Początku Andrzeja Szczypiorskiego zostały opisane odczucia Polaków patrzących na powstanie w getcie:

Stwórca odwracał oczy ku innym galaktykom, aby nie patrzeć na to, co zgotował nie tylko umiłowanemu ludowi, ale wszystkim ludziom ziemi, zhańbionym, współwinnym, podłym, bezradnym, zawstydzonym, a pośród wszystkich ludzi ziemi także temu człowiekowi, który stojąc na przystanku tramwajowym, dokładnie w miejscu, gdzie przed kilku dniami profesor Winiar padł na posterunku, powiedział pogodnie: - Żydki się smażą, aż skwierczy!27

Podobny obraz znajdziemy w relacji Heleny Merenholc, ocalałej z getta warszawskiego: „Wśród przechodniów słyszę: Żydki się smażą, święta nam psują, musimy przez nich chodzić piechotą"28, a także w pamiętnikach z okresu okupacji szczebrzeszyńskiego lekarza Zygmunta Klukowskiego ${ }^{29}$.

W.W. Van Dijk, J.W. Ouwerkerk, S. Goslinga, M. Nieweg, M. Gallucci When People Fall from Grace: Reconsidering the Role of Envy in Schadenfreude, "Emotion” 2006 No. 6/1, s. 156-160.

A. Leder Prześniona rewolucja. Ćwiczenia z logiki historycznej, Wydawnictwo Krytyki Politycznej, Warszawa 2014.

A. Szczypiorski Początek, Vol. 418, Instytut Literacki, Paryż 1986. Nie żałuję ani jednego dnia spędzonego w getcie - Rozmowa z Heleną Merenholc, w: B. Engelking Na łące popiołów. Ocaleni z Holocaustu, Cyklady, Warszawa 1993, s. 208. 
Na drugim krańcu emocjonalnych reakcji bystanderów znajduje się reakcja empatyczna. Psychologia wyróżnia empatię emocjonalną (afektywną), czyli zdolność do emocjonalnego reagowania na emocje innego człowieka - współodczuwanie jego cierpienia, smutku - oraz poznawczą - czyli umiejętność przyjęcia perspektywy innego człowieka, popatrzenie na świat „jego oczami”30. Dla zrozumienia zachowań w czasie Holokaustu szczególnie ważne wydaje się zrozumienie empatii emocjonalnej, na którą składają się empatyczna troska (współodczuwanie cierpienia) i osobisty dystres (dyskomfort i lęk odczuwane na widok cierpienia innego człowieka).Współczesne neurofizjologiczne badania empatii ${ }^{31}$ wskazują na specyficzne okolice mózgu, które aktywizują się na widok czyjegoś bólu fizycznego (głównie lewa część wyspy) i bólu emocjonalnego (kora przedczołowa). Świadomość cierpienia innego człowieka aktywizuje więc te same okolice mózgowia, które aktywizują się w sytuacji odczuwania bólu fizycznego. Co więcej, ograniczenie wrażliwości na ból (np. poprzez podanie badanym paracetamolu) ogranicza ich zdolność do empatyzowania ${ }^{32}$. Z jednej strony empatia jest więc automatyczna - z drugiej strony, nie wszystkim jest ona dana, bowiem istnieje znaczne zróżnicowanie zdolności do empatyzowania. Istnieją też konkretne czynniki ograniczające empatię. Należą do nich emocje obrzydzenia uruchamiane choćby przez specyficzny wizerunek innych osób jako stanowiących biologiczne zagrożenie. Obrazy takie są w stanie obniżyć aktywność kory przedczołowej, a zatem powstrzymać współodczuwania bólu emocjonalnego $^{33}$. Propaganda nazistowska skierowana do narodów okupowanej Europy miała na celu powiązanie wizerunku Żyda z zagrożeniem biologicznym Żydów na plakatach wiszących na ulicach polskich miast przedstawiano jako szczury, insekty, źródło chorób ${ }^{34}$. Celem takiej kampanii było powstrzymanie

30 M.H. Davis Empathy: A social psychological approach Routledge, New York 2018.

31 E. Bruneau, A. Pluta, R. Saxe Distinct Roles of the 'Shared Pain'and 'Theory of Mind'Networks in Processing Others'Emotional Suffering , "Neuropsychologia” 2012 No. 50/2, s. 219-231.

32 D. Mischkowski, J. Crocker, B.M. Way From Painkiller to Empathy Killer: Acetaminophen (Paracetamol) Reduces Empathy for Pain, "Social Cognitive and Affective Neuroscience" 2016 No. 11/9, S. $1345-1353$.

33 L.T. Harris, S.T. Fiske Dehumanizing the Lowest of the Low: Neuroimaging Responses to Extreme Out-Groups, „Psychological Science” 2006 No. 17/10, s. 847-853.

34 M. Bilewicz, J.R. Vollhardt Evil Transformations: Social-Psychological Processes Underlying Genocide and Mass Killing, w: Social Psychology of Social Problems: The Intergroup Context, ed. by A. Golec de Zavala, A. Cichocka, Palgrave Macmillan, Basingstoke 2012, s. 280-307. 
empatycznej reakcji wobec uciekinierów z gett i osób poszukujących pomocy po „aryjskiej stronie”.

Przykładów empatycznej reakcji etnicznych Polaków wobec powstania w getcie warszawskim znajdziemy również całkiem sporo we wspomnieniach z czasów okupacji - zarówno polskich, jak i żydowskich.

Getto ciągle się pali. Wiatr wieje na wschód, więc cała Warszawa krztusi się dymem, co jej słusznie przypomina tę tragedię ludzką. Nie mogę się pogodzić z tą myślą. [...] Jestem tak przygnębiony, tak przybity, jak nigdy. I ten wstyd za poniewierane człowieczeństwo!

- pisze w swoim wojennym dzienniku aktor i reżyser teatralny Marian Wyrzykowski. Jeden z przywódców powstania w getcie, Icchak Cukierman „Antek", pisze o tym okresie:

Wówczas panowała duża sympatia dla Żydów, bo wszyscy rozumieli że podjęta przez nich walka skierowana była przeciw Niemcom, a odwaga i siła Żydów budziły uznanie, ale byli i tacy, głównie ludzie z półświatka, którzy widzieli w nas tylko wszy wyskakujące z płonących domów. Ale nie wolno robić na podstawie tego uogólnień. Widziałem na własne oczy płaczących Polaków - stali i płakali. ${ }^{35}$

Najbardziej typową reakcją emocjonalną bystanderów jest jednak obojętność, o czym przekonują cytowane powyżej kroniki Ludwika Landaua. Reakcja wydawać się może szczególnie psychologicznie adaptacyjna w sytuacji, gdy zachowania pomocowe są skrajnie ryzykowne, co zapewne ogranicza tendencję do odczuwania współczucia - a jednocześnie odczuwanie schadenfreude jest w wielu kręgach moralnie nieakceptowane.

\section{Działania wobec Zagłady: sprawcze oblicze bystandera}

O działaniach bystanderów wobec zagłady Żydów napisano już bardzo wiele $^{36}$, zatem celem poniższego fragmentu nie będzie dokładny przegląd

Y. Zuckerman Nadmiar pamięci, PWN, Warszawa 2000, s. 432.

Por. np B. Engelking-Boni Szanowny panie gistapo. Donosy do władz niemieckich w Warszawie i okolicach w latach, 1940-1941, w: Prowincja noc. Życie i zagłada Żydów w dystrykcie warszawskim, red. B. Engelking-Boni, J. Leociak, D. Libionka, Wydawnictwo IFiS PAN, Warszawa 2007; 
zachowań Polaków w czasie Holokaustu. Wiadomo również, że mamy tu do czynienia z rzeczywistością niezwykle złożoną i wymykającą się prostym etycznym osądom (o czym świadczy chociażby wielość motywacji do udzielania pomocy Żydom poza gettem, od empatycznych po czysto materialne) ${ }^{37}$.

Na potrzeby tego artykułu omówimy trzy typy idealne zachowań polskich bystanderów wobec Żydów w czasie okupacji. Pierwsze z nich to zachowania pomocowe. Jak zauważyliśmy wcześniej, istnieje kilka konkurencyjnych modeli psychologicznych wyjaśniających źródła zachowań pomocowych. Pierwszy przyjmuje czynniki kontekstu społecznego (brak rozproszenia odpowiedzialności) oraz ocenę sytuacji jako wymagającą reakcji ${ }^{38}$. Drugi wskazuje na kalkulację korzyści i kosztów ${ }^{39}$ - przy czym na terenie Generalnego Gubernatorstwa drastyczność kary za udzielenie pomocy czyniła zachowania pomocowe jeszcze mniej prawdopodobnymi. Trzeci wskazuje na automatyzm udzielania pomocy - jako że jej źródłem jest empatyczna troska i emocjonalne współodczuwanie bólu, które staje się w pewnym momencie nie do zniesienia ${ }^{40}$.W kolejnej koncepcji - rozwijanej przez polskich badaczy od lat 8o. - przyjmuje się, że poza motywami endocentrycznymi (unikanie bólu, moralna gratyfikacja i inne korzyści) o pomaganiu decydują też motywy egzocentryczne, a więc nakierowane na przywracanie porządku moralnego w świecie zewnętrznym ${ }^{41}$.

To ostatnie podejście zdaje się tłumaczyć zachowania pomocowe i bierność w epoce Holokaustu. Samuel i Pearl Olinerowie, którzy prowadzili szeroko zakrojone badania na ten temat, poszukiwali „osobowości altruistycznej", czyli cech psychologicznych determinujących ratowanie Żydów

J. Grabowski Judenjagd. Polowanie na Żydów 1942-1945. Studium dziejów pewnego powiatu, Stowarzyszenie Centrum Badań nad Zagładą Żydów, Warszawa 2011; W. Bartoszewski Ten jest z ojczyzny mojej, Znak, Kraków 1969.

37 J. Tokarska-Bakir Sprawiedliwi Niesprawiedliwi, Niesprawiedliwi Sprawiedliwi, „Zagłada Żydów. Studia i Materiały" 2008 No. 4, S. 170-214.

38 B. Latané, J.M. Darley Bystander Apathy, „American Scientist” 1969 No. 57/2, s. 244-268.

39 I.M. Piliavin, J.A. Piliavin, J. Rodin Costs Diffusion, and the Stigmatized Victim, „Journal of Personality and Social Psychology" 1975 No. 32/3, s. 429-438.

40 D. Batson i in. Compassion or Compliance: Alternative Dispositional Attributions for One's Helping Behavior, "Social Psychology Quarterly" 1979 No. 42/4, s. 405-409.

41 J. Karyłowski $O$ dwóch typach altruizmu: badania nad endo- i egzocentrycznymi źródłami podejmowania bezinteresownych działań na rzecz innych ludzi, Ossolineum, Wrocław 1982. 
przez ich nieżydowskich sąsiadów. Olinerowie porównali cechy osobowości, wartości, a także inne charakterystyki społeczno-demograficzne osób ratujących Żydów, innych uczestników antynazistowskiego ruchu oporu (ale nieratujących Żydów) oraz ludzi niezaangażowanych w żadne formy oporu. W porównaniu tym wykazali, że bardzo trudno znaleźć cechy wyraźnie odróżniające ratujących od nieratujących: w obu grupach był podobny odsetek osób religijnych, ateistów, osób o przekonaniach lewicowych, prawicowych. Tym, co odróżniało ratujących, był specyficzny zestaw wartości związanych z pomaganiem i altruizmem. Co ciekawe, ratujący byli też częściej normocentryczni - tzn. przywiązani bardzo silnie do zasad i norm, w których zostali wychowani. W tym sensie można zauważyć, że to raczej świadomość norm i egzocentryczne motywacje determinowały ratowanie - a ich brak skłaniał do bierności w sytuacji ekstremalnej ${ }^{42}$.

Jeśli chodzi o zachowania niemoralne bystanderów w epoce Holokaustu, to brakuje jakichkolwiek systematycznych badań, które mogłyby wskazać na motywacje czy też psychologiczne charakterystyki osób zajmujących się szmalcownictwem czy też w inny sposób aktywnie uczestniczących w zagładzie Żydów. Historycy, podobnie jak niektórzy psychologowie, wskazują na motywację instrumentalną - chęć wzbogacenia się, podwyższenia statusu ${ }^{43}$. Tłumaczyć by to mogło zachowania Greków, Polaków czy Litwinów wobec deportacji Żydów ${ }^{44}$, ale też cywilnej ludności Berlina przejmującej mienie żydowskie ${ }^{45}$.

Wśród literatury wspomnieniowej podejmującej ten temat warto zwrócić szczególną uwagę na pamiętniki Zygmunta Klukowskiego ze Szczebrzeszyna. Opisuje on dokładnie współudział Polaków w zbrodniach na Żydach - jednocześnie pisząc z perspektywy silnie empatyzującej z ofiarami. Przykładem może być notatka z 22 października 1942 roku:

M. Smoleńska, J. Reykowski Motivations of People Who Helped Jews Survive the Nazi Occupation w: Embracing the Other: Philosophical, Psychological, and Historical Perspectives on Altruism, ed. by P. Oliner i in., NYU Press, New York 1992 , s. 213-225.

43 R.F. Baumeister The Holocaust and the Four Roots of Evil, w: Understanding Genocide: The Social Psychology of the Holocaust, ed. by L.S. Newman R. Erbrer, Oxford University Press, Oxford 2002, s. 241-458.

44 J.T. Gross, I. Grudzińska-Gross Złote żniwa: rzecz o tym, co się działo na obrzeżach zagłady Żydów, Znak, Kraków 2011.

A. Götz Hitler's Beneficiaries: Plunder, Racial War, and the Nazi Welfare State, Macmillan, New York 2007. 
Wciąż trwa tropienie Żydów. Obcy żandarmi i esesmani wyjechali wczoraj. Dzisiaj działają nasi żandarmi i granatowi policjanci, którym kazano zabijać na miejscu każdego złapanego Żyda. Rozkaz ten wykonują bardzo gorliwie. [...] Mieszkania żydowskie są częściowo opieczętowane, pomimo to rabunek idzie na całego. W ogóle ludność polska nie zachowywała się poprawnie. Niektórzy brali czynny udział w tropieniu i wynajdywaniu Żydów. Wskazywali, gdzie są ukryci Żydzi, chłopcy uganiali się nawet za małymi dziećmi żydowskimi, które policjanci zabijali na oczach wszystkich.W ogóle działy się straszne rzeczy, potworne, koszmarne, od których włosy stają na głowie. ${ }^{46}$

Między współudziałem w zbrodni a bezinteresownym zaangażowaniem w ratowanie Żydów rozciąga się oczywiście szerokie spektrum zachowań bystanderów, które znalazło swój wyraz w literaturze Holokaustu, a także w licznych opracowaniach naukowych. Oszacowanie częstości tych zachowań wśród etnicznych Polaków ${ }^{47}$ w czasie okupacji, a tym bardziej oszacowanie skali emocji bystanderów sprawia trudność. Brak obiektywnych danych powoduje,że współczesna wiedza Polaków na temat bystanderów stanowi raczej wyobrażenie na temat zjawiska i obrazuje proces społecznego konstruowania historii - czyli jej społeczną reprezentację ${ }^{48}$. Poniżej przedstawimy kilka wyników badań społecznych reprezentacji bystanderów czasu Holokaustu.

\section{Polacy o zachowaniach rodaków w czasie Holokaustu: wyniki badania sondażowego na temat społecznych reprezentacji bystandera}

Badanie społecznych reprezentacji zachowań etnicznych Polaków wobec Żydów w czasie Holokaustu przeprowadziliśmy metodą sondażu internetowego na ogólnopolskiej próbie reprezentatywnej pod względem płci, wieku

46 Z. Klukowski Zamojszczyzna, t. 1: (1918-1943), Ośrodek Karta, Warszawa 2007.

47 Pewnej próby w skali Warszawy dokonał Gunnar Paulson w pracy Utajone Miasto (S. Gunnar Utajone miasto. Żydzi po aryjskiej stronie Warszawy, przeł. E. Olender-Dmowska, Znak, Kraków 2007), jednakże jego szacunki spotkały się z krytyką badaczy tej tematyki (np. H. Dreifuss Utajone miasta. Kilka uwag o metodologii..., "Zagłada Żydów” 2014 No. 10).

48 Np. S. Moscovici Social Representations: Explorations in Social Psychology, New York University Press, New York 2001; D. Hilton, J. Liu History as the Narrative of a People: From Function to Structure and Content, "Memory Studies” 2017 No. 10/3, S. 297-309; D. Páez, M. Bobowik, J. Liu Social Representations of the Past and Competences in History Education, w: Palgrave Handbook of Research in Historical Culture and Education, Palgrave Macmillan, London 2017, s. 491-510. 
i miejsca zamieszkania Polaków ( $N$ = 610 osób; kobiety stanowiły $51,6 \%$ próby).

Poprosiliśmy respondentów o oszacowanie w procentach, ilu Polaków przejawiało daną postawę w trakcie okupacji niemieckiej. Badani otrzymali następującą instrukcję: „Historycy debatują na temat postaw różnych narodów w trakcie drugiej wojny światowej. Chcielibyśmy poznać Pana/ Pani zdanie na temat postaw Polaków w tamtym okresie". Po zapoznaniu się $\mathrm{z}$ instrukcją respondenci mieli za zadanie uzupełnić zdania zaznaczając na skali od o\% („nikt”) do 100\% („wszyscy”), jak bardzo powszechne wśród Polaków były przedstawione im postawy. Pytania dotyczyły pasywnych (emocjonalnych) reakcji bystanderów o zróżnicowanym poziomie moralności (\% Polaków współczuło Żydom w czasie II wojny światowej; \% Polaków bezinteresownie ratowało Żydów; \% Polaków było obojętnych na cierpienie Żydów w czasie II wojny światowej) oraz aktywnych (behawioralnych) reakcji bystanderów również o zróżnicowanym poziomie moralności (\% Polaków bezinteresownie ratowało Żydów w czasie II wojny światowej; \% Polaków odmówiło Żydom pomocy w czasie II wojny światowej; \% Polaków współpracowało z Niemcami w ich działaniach przeciw Żydom w czasie II wojny światowej). W ten sposób badani odpowiadali na pytania o emocje o różnym stopniu moralności (empatia, obojętność oraz schadenfreude) oraz pytania o zachowania o różnym stopniu moralności (bezinteresowna pomoc, odmówienie pomocy oraz współpraca ze sprawcami). Na poniższym wykresie przedstawiono średnie wyniki dla badanej populacji.

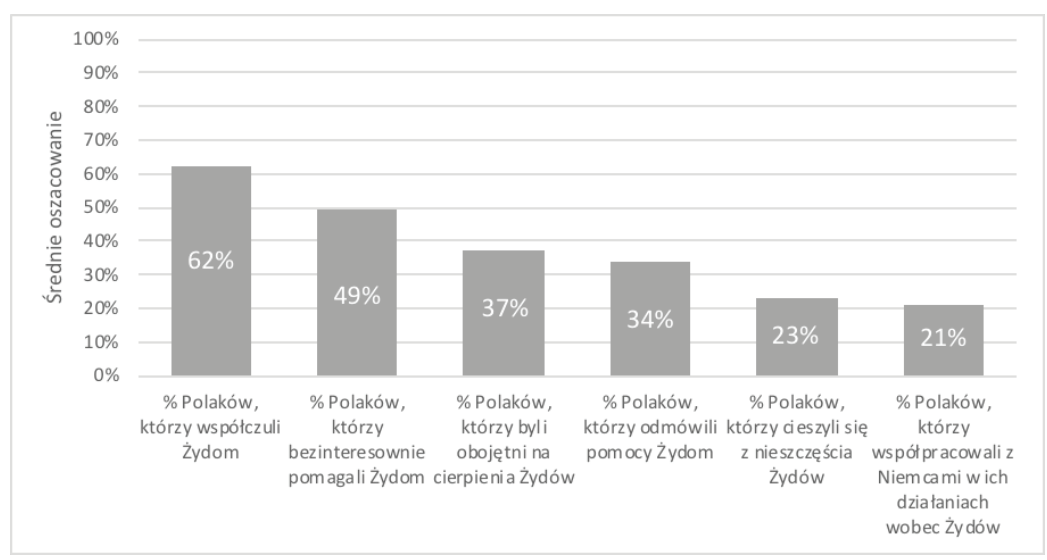

Ryc. 2. Średnie oszacowania postaw etnicznych Polaków wobec Żydów w czasie okupacji niemieckiej przez współczesnych Polaków. 
Polacy uważają za najczęstsze w czasie okupacji emocje i zachowania moralne - a za najrzadsze zachowania i emocje niemoralne. Jednocześnie nieco zaskakuje częstość wskazań na zachowania niemoralne. Przeciętny Polak twierdzi, że co piąty Polak w czasie okupacji współpracował z Niemcami w zagładzie Żydów i cieszył się z nieszczęścia Żydów (schadenfreude). Stosunkowo niedoszacowane wydają się zachowania obojętne i bierne - które w populacji wydają się najczęstsze (na co wskazują choćby omawiane powyżej oceny historyka Ludwika Landaua). Przeciętny Polak twierdzi, że co trzeci Polak odmówił pomocy Żydom i był generalnie obojętny na cierpienia Żydów.

Społeczna reprezentacja okresu okupacji w Polsce zdaje się być wypełniona postawami moralnie silnie nacechowanymi - zarówno moralnymi, jak i niemoralnymi. To bierność jest raczej wymazywana z obrazu lat okupacji. Jednocześnie widoczna jest też asymetria postrzegania emocji i zachowań niemoralnych i moralnych. Badani jako zdecydowanie częstsze uważają zachowania moralne. Warto jednak podkreślić, że tylko 3\% badanych zaznaczyło „0\%", szacując liczbę Polaków współpracujących z Żydami. Wydaje się więc, że świadomość jakichś form kolaboracji jest w Polsce stosunkowo powszechna.

W badaniu tym postanowiliśmy też zastanowić się nad tym, kim są osoby przeszacowujące moralne zachowania rodaków i niedoszacowujące zachowania niemoralne. Sprawdzaliśmy więc, czy osoby o wyższym poziomie antysemityzmu, narcyzmu kolektywnego i przekonani o własnej moralności będą przeszacowywać moralność własnego narodu w czasie okupacji. Z jednej strony sprawdzaliśmy więc, czy negowanie niemoralnych zachowań Polaków w latach okupacji jest przejawem antysemickiego imaginarium, w którym Żydów przedstawia się jako niewdzięcznych i biernych odbiorców pomocy ${ }^{49}$. Drugą hipotezę wywiedliśmy z badań nad narcystycznymi formami tożsamości narodowej, które opierają się na idealizacji moralności własnego narodu i nierealistycznych urojeniach wielkościowych - za czym ukryta jest fundamentalna niepewność co do kolektywnej samooceny. Osoby narcystycznie przywiązane do polskości przejawiają silniejsze uprzedzenia antysemickie i skłonne są postrzegać własny naród jako oblężoną twierdzę, przeciw której skierowane są knowania innych narodów ${ }^{50}$.W końcu postanowiliśmy sprawdzić też hipotezę, że skłonność do przeszacowywania moralności zachowań

49 E. Janicka, J. Tokarska-Bakir Sublokatorstwo jako kategoria kultury polskiej, „Studia Litteraria et Historica" 2014 No. 2, S. 1-2.

50 A. Golec de Zavala, A. Cichocka Collective Narcissism and Anti-Semitism in Poland " Group Processes \& Intergroup Relations" 2012 No. 15/2, S. 213-229. 
Polaków wobec Żydów i niedoszacowywania zachowań niemoralnych ${ }^{51}$ może być wynikiem ogólnej tendencji do idealizowania własnej moralności. Osoby niezdolne do dostrzegania własnej niemoralności mogą dokonywać projekcji na naród - i nie być zdolne do dostrzeżenia również niemoralnych zachowań własnego narodu.

W tym celu przeprowadziliśmy serię korelacji między kolektywnym narcyzmem (mierzonym skalą kolektywnego narcyzmu), antysemityzmem (mierzonym skalą antysemityzmu spiskowego) oraz zawyżaniem własnej moralności (mierzonym jedną pozycją, w której badanych pytaliśmy, jak często łamią zasady moralne w swoim codziennym życiu), a poszczególnymi reprezentacjami stosunku Polaków do Żydów w czasie okupacji (szacowanymi procentami konkretnych zachowań).

\begin{tabular}{lccc}
\hline & $\begin{array}{c}\text { Przekonanie } \\
\text { o własnej } \\
\text { moralności }\end{array}$ & $\begin{array}{c}\text { Kolektywny } \\
\text { narcyzm }\end{array}$ & $\begin{array}{c}\text { Antysemityzm } \\
\text { spiskowy }\end{array}$ \\
\hline $\begin{array}{l}\text { 1. Procent Polaków współczują- } \\
\text { cych Żydom }\end{array}$ & $0,12^{* *}$ & $0,21^{* *}$ & 0,05 \\
$\begin{array}{l}\text { 2. Procent Polaków bezinteresow- } \\
\text { nie pomagających Żydom }\end{array}$ & $-0,10^{* *}$ & $0,32^{* *}$ & $0,16^{* *}$ \\
$\begin{array}{l}\text { 3. Procent Polaków obojętnych na } \\
\text { cierpienie Żydów }\end{array}$ & $-0,16^{* *}$ & 0,00 & $0,14^{* *}$ \\
$\begin{array}{l}\text { 4. Procent Polaków, którzy odmó- } \\
\text { wili pomocy Żydom }\end{array}$ & $-0,25^{* *}$ & $-0,08$ & 0,00 \\
$\begin{array}{l}\text { 5. Procent Polaków cieszących się } \\
\text { z nieszczęścia Żydów }\end{array}$ & $-0,32^{* *}$ & 0,00 & $0,09^{* *}$ \\
$\begin{array}{l}\text { 6. Procent Polaków współpracują- } \\
\text { cych z Niemcami w ich działa- } \\
\text { niach wobec Żydów }\end{array}$ & $-0,36^{* *}$ & 0,03 & 0,01 \\
\hline
\end{tabular}

Tabela 1. Związek przekonań o własnej moralności, kolektywnego narcyzmu i antysemityzmu spiskowego z poszczególnymi reprezentacjami stosunków etnicznych Polaków do Żydów w czasie okupacji (korelacje $r$-Pearsona, gwiazdką zaznaczono istotność na poziomie $p<0,05$; dwiema gwiazdkami zaznaczono istotność na poziomie $p<0,01$ ).

51 C. Leach, C. Wayne, N. Ellemers, M. Barreto Group Virtue: The Importance of Morality (Vs. Competence and Sociability) in the Positive Evaluation of In-Groups, "Journal of Personality and Social Psychology" 2007 No. 93/2, s. 234-230. 
Wyniki analizy korelacji wskazują, że związki antysemityzmu i kolektywnego narcyzmu z reprezentacjami przeszłości nie mają charakteru systematycznego. Osoby narcystyczne zdecydowanie przeszacowywały skalę zachowań i moralnych emocji Polaków, jednak narcyzm okazał się niezwiązany z ocenami zachowań i emocji niemoralnych. Osoby o przekonaniach antysemickich przeszacowywały skalę ratowania Żydów, jednak korelacje z innymi zmiennymi nie były spójne. Najsilniejsze i najbardziej spójne wyniki zaobserwowaliśmy w wypadku ocen własnej moralności. Badani, którzy nie byli w stanie uznać własnej niemoralności (a zatem uznawali, że nigdy nie łamią zasad moralnych), najbardziej tendencyjnie postrzegali historię własnego narodu - zaniżając częstość zachowań niemoralnych i przeszacowując częstość zachowań moralnych. Osoby zdolne do autokrytycyzmu (dostrzegające własne transgresje moralne) były najbardziej gotowe przyznać, że wśród ich rodaków znajdowały się osoby odczuwające emocje niemoralne (schadenfreude) i zachowujące się w sposób niemoralny (kolaboracja). Poniższy wykres obrazuje kierunek tej zależności.

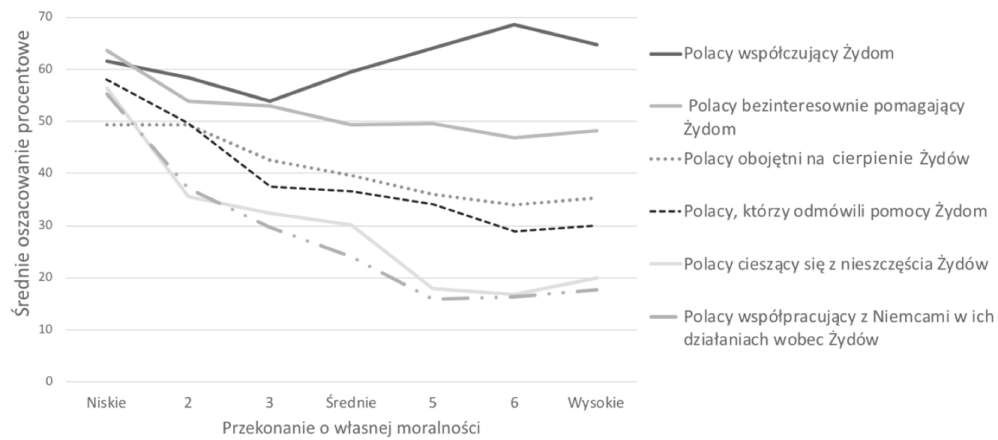

Ryc. 3. Średnie oszacowania postaw etnicznych Polaków wobec Żydów w czasie okupacji niemieckiej w zależności od przekonania o własnej moralności.

\section{Podsumowanie}

Pojęcie bystandera, wypracowane na gruncie psychologii społecznej w latach 6o. i 70., stało się dziś jedną z podstawowych kategorii opisu Holokaustu. Sposób użycia tego pojęcia jest jednak ograniczony i koncentruje się wyłącznie na biernym aspekcie bycia bystanderem. Rola bystandera otwiera 
jednak możliwość nie tylko zachowań różniących się na wymiarze moralności (od ratowania do kolaboracji ze sprawcami), lecz również szeregu zróżnicowanych moralnie emocji (od empatii do schadenfreude). W przedstawionym powyżej badaniu próbowaliśmy sprawdzić, w jakim stopniu różne oblicza bystandera epoki Holokaustu tworzą podzielaną wiedzę zbiorową Polaków na temat przeszłości. Chcieliśmy sprawdzić, jak Polacy widzą relacje polsko-żydowskie w czasie Zagłady. Badanie to dowiodło, że poza dobrze znanymi wzorcami pamięci zbiorowej (przeszacowywanie moralnych zachowań rodaków) w reprezentacjach społecznych Holokaustu dominują wyobrażenia o moralnej nieobojętności - Polacy są postrzegani jako ratujący i empatyczni albo jako kolaborujący i zawistni. Kategoria biernych emocji i zachowań, która w większości wydarzeń historycznych jest najczęstsza, była relatywnie rzadko odnoszona przez badanych Polaków do opisu historii lat okupacji.

Wyidealizowane społeczne reprezentacje Holokaustu w Polsce są jednak nie tylko efektem antysemityzmu czy narcystycznego rozumienia tożsamości. Są również, a może w szczególności, projekcją iluzji na temat własnej moralności. Osoby niedostrzegające własnych transgresji moralnych nie są również zdolne do przyznania, że wśród ich narodu zdarzały się w przeszłości zachowania niemoralne, a czasem i zbrodnicze. Zdolność do dostrzeżenia własnej niemoralności jest więc kluczem do pojednania historycznego i przepracowania niemoralnych aspektów własnego narodu. 


\section{Abstract}

\section{Michał Bilewicz}

UNIVERSITY OF WARSAW

\section{Maria Babińska}

UNIVERSITY OF WARSAW

Bystanders - Who Are They? Poles'Current Perceptions of Attitudes Towards /ews During the Nazi Occupation

Holocaust researchers have come to question the term "bystander" and its exclusive focus on passivity. Recent psychological research on witnesses of crime and their reactions foregrounds actions and emotions that vary greatly in terms of ethics, ranging from rescuing to collaboration, from empathy to schadenfreude. Bilewicz and Babińska examine to what extent these different aspects of being a witness currently shape Poles' collective notions on Polish attitudes towards Jews during the occupation. Their research suggests that apart the from well-known models of collective memory (which often overestimate the morality of the Poles' actions), dominant representations of the Holocaust tend to underemphasize the witnesses' indifference: Poles are perceived as either as empathic rescuers or as envious collaborators. Few of the Poles surveyed mentioned passive emotions and behaviours when describing their ideas about Poland during the occupation.

\section{Keywords}

witness, bystander, Holocaust, help, empathy, schadenfreude 